\title{
Expression of resistance gene analogs in woodland strawberry (Fragaria vesca) during infection with Phytophthora cactorum
}

\author{
Xiao-Ren Chen ${ }^{1,2}$ - May Bente Brurberg ${ }^{1}$ Abdelhameed Elameen ${ }^{1} \cdot$ \\ Sonja Sletner Klemsdal ${ }^{1}$ - Inger Martinussen ${ }^{1}$
}

Received: 19 January 2016 / Accepted: 12 July 2016 / Published online: 22 July 2016

(C) The Author(s) 2016. This article is published with open access at Springerlink.com

\begin{abstract}
Important losses in strawberry production are often caused by the oomycete Phytophthora cactorum, the causal agent of crown rot. However, very limited studies at molecular levels exist of the mechanisms related to strawberry resistance against this pathogen. To begin to rectify this situation, a PCR-based approach (NBS profiling) was used to isolate strawberry resistance gene analogs (RGAs) with altered expression in response to $P$. cactorum during a time course (2, 4, 6, 24, 48, 96 and $192 \mathrm{~h}$ post-infection). Twenty-three distinct RGA fragments of the NB-LRR type were identified from a resistance genotype (Bukammen) of the wild species Fragaria vesca. The gene transcriptional profiles after infection showed that the response of most RGAs was quicker and stronger in the resistance genotype (Bukammen) than in the susceptible one (FDP821) during the early infection stage. The transcriptional patterns of one RGA (RGA109) were further monitored and compared during the P. cactorum infection of two pairs of resistant and susceptible genotype combinations (Bukammen/FDP821 and FDR1218/1603). The $5^{\prime}$ end sequence was cloned, and its putative protein was characteristic of NBS-LRR R protein. Our results yielded a first insight into the strawberry RGAs responding to P. cactorum infection at molecular level.
\end{abstract}

Communicated by S. Hohmann.

Inger Martinussen

inger.martinussen@nibio.no

1 Norwegian Institute of Bioeconomy Research, Box 115, 1431 Ås, Norway

2 College of Horticulture and Plant Protection, Yangzhou University, Wenhui Eastern Road 48, Yangzhou 225009, Jiangsu Province, China
Keywords Strawberry $\cdot$ Crown rot disease $\cdot$ Phytophthora cactorum $\cdot$ NBS-LRR genes $\cdot$ Resistance gene analogs

\author{
Abbreviations \\ RGA Resistance gene analog \\ Hpi Hours post-infection \\ NBS-LRR Nucleotide binding site and leucine-rich repeat
}

\section{Introduction}

Plants are often attacked by a great number of pests, including viruses, bacteria, nematodes, insects, fungi, and oomycetes. However, they have evolved elaborate mechanism to protect themselves against the attackers (Dangl and Jones 2001). One of the efficient defense mechanisms is a type of immunity that is described by the gene-forgene theory, which was proposed by Harold Henry Flor in the last century $(1942,1971)$. The induction of the plant defense response is considered to be initiated through the recognition of specific effectors encoded by Avr (avirulence) genes of the pathogens by the complementary products of the genes conferring resistance, the $R$ genes of the host plants (Flor 1942, 1971). To date, more than 70 different genes for resistance ( $R$ genes) to major plant pathogens have been isolated and characterized from different plant species (Sharma et al. 2009; Gururani et al. 2012). Most of the $R$ genes discovered in plants have conserved functional domains and can be assigned to one of the five major classes of $R$ genes (Dangl and Jones 2001). The nucleotidebinding site (NBS)/leucine-rich repeats (LRRs) class is by far the predominant class, and their resistance gene analogs (RGAs) are numerous in plants and distributed over all chromosomes in some plant species (Meyers et al. 2002, 2003; Monosi et al. 2004). 
The conserved primary structure of resistance gene sequences has often been used to isolate RGAs by PCR, with degenerate primers designed from the highly conserved motifs of these proteins (Sharma et al. 2009). The NBS profiling technique is an example of a motif-directed profiling technique that targets $R$ genes and RGAs using degenerate primers that are homologous to the conserved motif sequences (P-loop, the kinase-2 motif, and the GLPL motif) in the NBS domain of the NBS-LRR class of $R$ genes. The degenerate primers are designed to recognize specifically a large number of NBS-LRR gene family members (Van der Linden et al. 2004). This technique has been successfully used to identify $R$ genes and RGAs in apple, lettuce, potato, tomato, wheat, and barley (Van der Linden et al. 2004; Calenge et al. 2005; Mantovani et al. 2006; Syed et al. 2006; Malosetti et al. 2007). In addition to being a powerful tool for the identification of $R$-genes, NBS profiling technique has been used to generate candidate gene markers linked to $R$-gene loci which can be used in marker-assisted breeding (Brugmans et al. 2008; Jacobs et al. 2010; Jo et al. 2011).

Strawberry is an important horticultural crop grown in many tropical, subtropical, and temperate areas throughout the world with an annual production of approximately 4.5 million tons (2012-FAOSTAT Agriculture Data, http://faostat.fao.org). The main cultivated species around the world is the octoploid Fragaria $\times$ ananassa Duch. $(2 n=8 x=56)$ (Davis et al. 2007), while the most common native species, $F$. vesca L., is a diploid with 14 chromosomes (Oosumi et al. 2006). The annual strawberry production is strongly affected by phytopathogens, forcing the excessive use of chemicals to control them (Maas 1998). The destructive oomycete Phytophthora cactorum (Lebert and Cohn) Schröeter (1886) is a root pathogenic oomycete which causes crown rot in strawberry plants throughout the world (Erwin and Ribeiro 1996; Maas 1998). Crown rot disease has been an important limiting factor to successful strawberry production worldwide, because most cultivated strawberry cultivars are highly susceptible to attack by P. cactorum (Maas 1998; Eikemo et al. 2010; Chen et al. 2011). However, genotypes resistance to crown rot do exist (Eikemo et al. 2010), and management through host resistance has been considered as one of the best options available for crop protection.

Martínez-Zamora et al. (2004) reported for the first time on RGAs of the NBS-LRR class in strawberry. Seven distinct families of RGAs of the NBS-LRR type were identified from wild species $F$. vesca and $F$. chiloensis, and six different $F$. $\times$ ananassa cultivars, by genomic DNA amplification using degenerate primers. Jung et al. (2010) reported a cluster of four RGAs, contained in a strawberry ( $F$. vesca) fosmid (34E24), with NBS and LRR domains, and conserved in all the five rosid genomes with which they compared them. More recently, a number of strawberry RGAs with NBS-LRR domain were predicted (Perazzolli et al. 2014; Zhong et al. 2015). At least 144 NBS-LRR genes reportedly exist in strawberry genome based on a systematic genome-wide survey (Zhong et al. 2015). These detected RGAs could in principle be involved in strawberry resistance. However, no experimental evidence exists to link the presence or absence of any particular $R$ gene or RGA to disease resistance in strawberry.

Van de Weg (1997) found support for one single segregating dominant strawberry resistance gene (Rpf2), against the oomycete Phytophthora fragariae, while a dominant, two-gene model has been suggested in red raspberry (Rubus ideaus) resistance toward Phytophthora rubi (Pattison et al. 2007). For resistance to P. cactorum in stawberry, there are several reports indicating a more complex gene model (Shaw et al. 2006, 2008; DenoyesRothan et al. 2004). Focusing on a simpler system than the octoploid strawberry, e.g., a diploid model system, thus appears attractive to get an understanding of the nature and inheritance of the Phytophthora crown rot resistance.

The diploid woodland $F$. Vesca has been considered a model plant system for the Rosaceae family because of its attractive features, such as a small genome size $(\sim 240 \mathrm{Mb})$, available transformation protocol, released genome sequence, and short generation time (Alsheikh et al. 2002; Folta and Davis 2006; Shulaev et al. 2011). Genetic maps exist for both the diploid and octoploid strawberry (Davis and Yu 1997; Lerceteau-Köhler et al. 2003; Sargent et al. 2004, 2006; Cipriani et al. 2006; Folta and Davis 2006; Weebadde et al. 2008). A high degree of macrosynteny and colinearity between diploid and octoploid strawberry exists, and no major chromosomal rearrangements seem to have occurred (Folta and Davis 2006; Rousseau-Gueutin et al. 2008, 2009). It is thus reasonable to assume that these two strawberry species with their common ancestor employ similar resistance mechanisms against pathogen attacks, and it was recently found that diploid strawberry encompass a wide range of resistant phenotypes toward P. cactorum (Eikemo et al. 2010). Hence, in this study, the diploid strawberry was utilized to analyze strawberry resistance to $P$. cactorum infection.

Identification of resistance genes and an increased understanding of their expression pattern are very important to breed more resistant cultivars and/or to develop more effective disease management in the strawberry production. In the presented work, the expression of RGAs of NBS-LRR class in diploid strawberry facing P. cactorum infection was investigated using NBS profiling technique. The expression pattern of a limited number of RGAs was further monitored by real-time RT-PCR. This study 
constitutes a first step toward dissecting the molecular mechanisms of crown rot resistance in strawberry through identifying strawberry NBS-LRR RGAs to the causal agent P. cactorum.

\section{Materials and methods}

\section{Biological materials}

One isolate of Phytophthora cactorum (NIBIO isolate ID number 10300) was originally isolated from a diseased strawberry crown from a strawberry field at Ås, Norway. $P$. cactorum was routinely cultured on $10 \% \mathrm{~V} 8$ agar at $25^{\circ} \mathrm{C}$ (Erwin and Ribeiro 1996). Zoospore suspensions of P. cactorum were prepared as described previously (Chen et al. 2011).

Earlier 60 accessions/genotypes of diploid Fragaria sp. were tested for susceptibility to $P$. cactorum in greenhouse (Eikemo et al. 2010). Genotype FDP821 (Fragaria vesca subsp. americana) was graded as highly susceptible, while genotype Bukammen ( $F$. vesca) scored as resistant. The accession FDP821 was obtained from East Malling Research, East Malling, UK and Bukammen from NIBIO, Kvithamar, Norway. These genotypes were propagated as runner plants for the experiments. Propagation was done in a greenhouse at $16 \mathrm{~h}$ day $/ 20{ }^{\circ} \mathrm{C}$ and $8 \mathrm{~h}$ night $/ 14{ }^{\circ} \mathrm{C}$. High-pressure sodium lamps (SON/T, $120 \mu \mathrm{E} \mathrm{s}^{-1} \mathrm{~m}^{-2}$ ) were used to provide artificial light during the periods with less than $16 \mathrm{~h}$ of natural light. After multiplication and establishment, the plants were grown for an additional 1-2 weeks before inoculation with the pathogen.

\section{Strawberry inoculation}

Strawberry plants were inoculated with $P$. cactorum isolate 10300. Each plant was gently wounded by scraping their rhizome surface with a sterile scalpel and inoculated by adding $2 \mathrm{ml}$ of the zoospore suspension $\left(1 \times 10^{5}\right.$ spores $\mathrm{ml}^{-1}$ ) onto the crown and lower parts of the plant with a pipette. Plants inoculated with sterile distilled water onto wounded crowns served as controls. All the treated plants were grown at $20{ }^{\circ} \mathrm{C}$. Tissue samples of the crown area (transition zone between root and shoot) were sampled at 0 , 2, 4, 6, 24, 48, 96, and $192 \mathrm{~h}$ post-infection (hpi). A number of replicate plants for each time point varied from 3 to 7 , and the experiment was biologically repeated twice. Additional strawberry plants of each genotype, inoculated and mock-inoculated, were kept for extra days after sample harvesting. These were used to follow the disease progression and, hence, to ensure the success of the inoculations. All collected samples were immediately put into liquid nitrogen and stored at $-80{ }^{\circ} \mathrm{C}$ until RNA extraction.

\section{Isolation of RNA and cDNA synthesis}

For each set time point, total RNA was extracted from 3 to 7 inoculated strawberry crowns using Qiagen RNeasy Plant Mini Kit (Qiagen, Hilden, Germany). The quality and yield of RNA samples were measured using Agilent RNA 6000 Nano Kit on Agilent 2100 Bioanalyzer (Agilent Technologies, CA, USA).

Prior to cDNA synthesis, RNA samples were treated with DNase I (TURBO DNA-free Kit, Ambion). cDNAs were synthesized from $1-\mu \mathrm{g}$ total RNA in a $20-\mu \mathrm{l}$ reaction using the random primer and Superscript III Reverse Transcriptase (Invitrogen, MA, USA) according to the manufacturer's instructions. SYBR green real-time RTPCR (without reverse transcriptase) with primers for the house-keeping gene actin (Table 1) was used to check that RNA samples were not contaminated with genomic DNA. cDNAs from each RNA sample extraction were made using BD SMART PCR cDNA Synthesis Kit (Clontech, CA, USA) according to the manufacturer's instruction and stored at $-20^{\circ} \mathrm{C}$ for later use.

\section{NBS profiling}

The samples from the resistant genotype Bukammen and the susceptible genotype FDP821 and four combinations of NBS-specific primers (NBS2, NBS3, NBS5, and NBS7) (van der Linden et al. 2004) were used in the NBS profiling. It was performed as described by van der Linden et al. (2004) with some modifications. First, NBS profiling was applied to cDNA instead of genomic DNA. This can be instrumental in identifying those members of an $R$ gene cluster that are transcribed, and thus putatively functional. Second, restriction digestion and adaptor ligation were made in the same $60-\mu 1$ reaction in one step. The $60-\mu 1$ reaction mixture contained $200 \mathrm{ng}$ of cDNA, $10 \mathrm{mM}$ Tris-HAC (pH7.5), $10 \mathrm{mM} \mathrm{MgAc} 2,50 \mathrm{mM} \mathrm{KAc,} 5 \mathrm{mM}$ DTT, $50 \mathrm{ng}$ BSA, $1.2 \mathrm{nmol}$ adaptor mix, $1 \mathrm{mM}$ ATP, $10 \mathrm{U}$ Rsa I, and 1 U T4 DNA ligase. The reaction was incubated at $37{ }^{\circ} \mathrm{C}$ for $3 \mathrm{~h}$, and enzymes were inactivated at $65{ }^{\circ} \mathrm{C}$ for $15 \mathrm{~min}$. The restriction/ligation mixture was diluted twofold with sterile water and used as template for PCR reactions.

Amplification of NBS-specific fragments was performed through a single PCR with NBS-specific primer and adaptor primer, rather than the 2-step PCR described in the original protocol (van der Linden et al. 2004). The 25- $\mu 1$ PCR reaction mixture consisted of 5- $\mu$ l template cDNA, 20 pmol of both adaptor primer and NBS primer, $0.2 \mathrm{mM}$ dNTPs, 0.2 U HotStarTaq (Qiagen), and 2.5 $\mu$ l HotStarTaq PCR buffer (with $1.5 \mathrm{mM} \mathrm{MgCl}_{2}$ ). The PCR reaction was: $15 \mathrm{~min}$ at $95{ }^{\circ} \mathrm{C}$ (to activate HotStarTaq polymerase), 35 cycles at $95{ }^{\circ} \mathrm{C}$ for $30 \mathrm{~s}$ for denaturing, 1.4 minat $55^{\circ} \mathrm{C}$ (NBS5 and 
Table 1 Primers used for real-time RT-PCR expression analysis of strawberry RGAs

\begin{tabular}{llrll}
\hline Gene name & Accession no. & Amplicon size $(\mathrm{bp})$ & Forward primer $\left(5^{\prime}-3^{\prime}\right)$ & Reverse primer $\left(5^{\prime}-3^{\prime}\right)$ \\
\hline RGA2 & JZ390871 & 80 & TTCAGGAATTTGATGGATTGAA & AGAACCAACTCCTGAGAATGC \\
RGA5 & JZ390872 & 60 & TTTGGAGATCCATAGATGTTGC & GTAGCATGATGCGGCTACCA \\
RGA37 & JZ390875 & 81 & TGCAGAGTTGTGCAAAAGGT & GAGTGGTTGCTCTCATCATCC \\
RGA52 & JZ390877 & 110 & GGATGTCAACCTGTGGGGAAG & CCCCAAAACAGTATGATGCTA \\
RGA109 & JZ390878 & 66 & TGCTCGTCTGGTGACTTCAA & AGATCCCAACCTGATGCAAT \\
RGA116 & JZ390879 & 118 & CACCCATGGATTTTCTCGTT & GAACTTGTGGAGAAAATTGTGGA \\
RGA124 & JZ390880 & 116 & TGGGAGAAGAGGGATCAACA & ACCATGGCAAAGGATACCAG \\
RGA144 & JZ390881 & 106 & GCCTCCATTACTGGCTTCTTC & ACGGGAAACTGGCTCTCTTT \\
RGA147 & JZ390882 & 124 & GCAAAACGGAAAGATCTTGATT & GACAGGCAAACCGTCTTCTG \\
RGA156 & JZ390883 & 115 & GGTCCTGTCCATTGAAGAC & AAAAGGTTGCAGTGCTGGAG \\
RGA159 & JZ390884 & 110 & CTGGTGTTGCTCTTCATCCA & TGCAGAGCCAAGTGAAGACT \\
RGA169 & JZ390887 & 74 & ATATGCCAATCATGCGAACA & AATCGATTCTCGGGTAGAGGA \\
RGA173 & JZ390888 & 110 & CTGGAGTCCTGGCTCATGTT & TTGTTCAAGGGGATGACCTC \\
RGA176 & JZ390889 & 70 & GTGGACCCCAATGAGAGTGA & TACAAGACAAGCCATGGATAAGG \\
RGA194 & JZ390891 & 100 & TTGATTTGATTCCCCCTGAG & ATGATCAGCCACCTGCATTT \\
RGA195 & JZ390892 & 94 & CCAACCAGTTCGTCTTCCAT & GATCCCAAGGAGCAGCTACA \\
RGA196 & JZ390893 & 135 & ATGCCCCAAACAGAAACAAC & ACAACAACTGAGGCGGACTT \\
Actin & XM_011471474 & 106 & CTTTTGGATTGAGCCTCGTC & ACGAGCTGTTTTCCCTAGCA \\
\hline
\end{tabular}

NBS7) or $60{ }^{\circ} \mathrm{C}(\mathrm{NBS} 2$ and NBS3) for annealing, 2 min at $72{ }^{\circ} \mathrm{C}$, and a final extension at $72{ }^{\circ} \mathrm{C}$ for $20 \mathrm{~min}$.

Afterward, a second similar PCR reaction was performed using $5 \mu \mathrm{l}$ of the tenfold diluted first PCR product as template, and the same NBS-specific primer but now labeled radioactively using $\left[\gamma-{ }^{33} \mathrm{P}\right] \mathrm{dATP}$. The NBS-specific primer labeling was performed using T4-polynucleotide kinase from (New England Biolabs_-NEB, MA, USA) as described by Sambrook et al. (1989).

The PCR products were separated by electrophoresis on $6 \%$ polyacrylamide gels at $110 \mathrm{~W}$ for at least $3 \mathrm{~h}$ depending on the expected size of DNA fragments. After this, the gels were fixed on Whatman $3 \mathrm{MM}$ paper and dried at $80^{\circ} \mathrm{C}$ for 1 h. BioMax MR films (Kodak, NY, USA) were exposed to the dried gels at $-80{ }^{\circ} \mathrm{C}$ to visualize individual fragments.

In total, four NBS-specific primers (NBS2, NBS3, NBS5, and NBS7) and one enzyme (RsaI) were used. NBS2, NBS5, NBS7, and adaptor primer were the same as described by van der Linden et al. (2004), while the NBS3 was described by Wang et al. (2008). Positions of the NBS primers in the NBS domain are referred to in these papers.

\section{Sequence analysis of NBS fragments}

Electrophoresis and recovery of DNA fragments upregulated in the resistant genotype Bukammen and not in the susceptible genotype FDP821 were cut out from the dried polyacrylamide gels. The DNA recovery was performed as described by Liang et al. (2008), reamplified with PCR conditions identical to the first PCR of the NBS profiling protocol and purified with QIAquick PCR purification kit (Qiagen). After verification on agarose gels, PCR products were directly sequenced using the adaptor primer as a sequencing primer with the BigDye Terminator v3.1 Cycle Sequencing Kit (Applied Biosystems, MA, USA) and an ABI PrismTM 3100 Genetic Analyzer (Applied Biosystems) at the Norwegian University of Life Sciences (Ås, Norway). Sequences were searched against NCBI non-redundant database (http://www.ncbi.nlm.nih.gov) and the Genome Database for Rosaceae (GDR) (http:// www.rosaceae.org/). The searches were performed using BLASTx (Altschul et al. 1997) with an expected $(E)$ value cutoff of $10^{-4}$.

\section{SYBR green real-time RT-PCR assays}

Primer pairs (Table 1) were designed using Primer Express software v2.0 (Applied Biosystems). The specificity of the amplicons was checked by melting-curve analysis and by $3 \%$ agarose gel electrophoresis. The amplification efficiency of all primer pairs was evaluated from the slope of standard curves where efficiency $=10^{-1 / \text { slope }}($ Pfaffl 2001), and strawberry genomic DNA was used as a template. The strawberry housekeeping gene encoding actin was selected as the constitutively expressed internal control.

cDNA was diluted tenfold, and quantitative PCR was performed using $4 \mu \mathrm{l}$ cDNA in a $25-\mu \mathrm{l}$ final volume with Power SYBR green master mix (Applied Biosystem). The thermal cycling conditions included an initial heat-denaturing step at $95^{\circ} \mathrm{C}$ for $10 \mathrm{~min}, 40$ cycles of denaturing $\left(95^{\circ} \mathrm{C}\right.$ 
for $15 \mathrm{~s}$ ) and combined annealing and elongation (1 min, $60{ }^{\circ} \mathrm{C}$ ). Amplification was followed by melting curve analysis and determination of melting temperature (Tm) for the PCR products, as a control of amplification specificity. All reactions were performed in technical triplicate and three non-template (water) controls were included for each primer pair. The experiment was biologically repeated twice.

The expression level was estimated by the threshold cycle $(\mathrm{Ct})$ values of each gene. All results were analyzed using BestKeeper (Pfaffl et al. 2004) for calculation of the normalization factor. After normalization, the expression levels of all genes in different samples were compared against their expression in a sample selected as calibrator (see details in Results), using Ct values with the Relative Expression Software Tool (REST) (Pfaffl et al. 2002). The statistical significance was calculated by REST software using a pairwise fixed reallocation randomization test (Pfaffl et al. 2002).

\section{Gene cloning and sequence analysis}

For cloning of the gene corresponding to RGA fragment 109 , the annotated strawberry reference genome was used to design primers (primer sequences listed in Table 1, RGA 109 Forward: $5^{\prime}-3^{\prime}$; Reverse: $5^{\prime}-3^{\prime}$ ). The cDNA was used as PCR template to amplify the gene coding sequences. Cycling conditions for 30 cycles were $95^{\circ} \mathrm{C}$ for $15 \mathrm{~s}, 52^{\circ} \mathrm{C}$ for $30 \mathrm{~s}$, and $72{ }^{\circ} \mathrm{C}$ for $2 \mathrm{~min}$, with denaturation at $94{ }^{\circ} \mathrm{C}$ for 5 min and elongation at $72{ }^{\circ} \mathrm{C}$ for 5 min subsequently. The amplified products were purified and cloned into pCR2.1TOPO vector (Invitrogen), and five clones were sequenced by Sanger-based methods. For genes larger than $1 \mathrm{~kb}$ in length, additional gene-specific primers for sequencing were designed at an interval of 700 base pairs.

The open reading frames (ORFs) of genes were predicted using ORF Finder (http://www.ncbi.nlm.nih.gov/gorf/gorf. $\mathrm{html}$ ). Sequence alignments were conducted to investigate the relationship of the strawberry RGAs with other plants using the publicly available program BioEdit (Hall 1999). The full-length sequence, translated using BioEdit, was used to perform a protein-protein BLAST (BLASTP) search in NCBI database (http://www.ncbi.nlm.nih.gov/), and the protein sequences of other plant species were downloaded from the database. These sequences were then employed for multiple sequence alignments using BioEdit.

\section{Results}

\section{Isolation of strawberry RGAs differentially expressed during the $P$. cactorum infection}

To characterize RGAs involved in the strawberry response to $P$. cactorum infection, we identified RGAs differentially expressed upon infection using NBS profiling. For this purpose, the RGA expression profiles in a resistance genotype (Bukammen) and a susceptible one (FDP821) were investigated during an infection time course $(2,4,6,24,48$, 96, and 192 hpi) with $P$. cactorum. We anticipated that the RGAs present in the resistant genotype Bukammen and not in the susceptible FDP821 could be involved in strawberry plant disease resistance. Four combinations of NBS-specific primers (NBS2, NBS3, NBS5, and NBS7) with Rsa I were used in the NBS profiling. Each combination gave approximately $20-35$ bands per lane.

\section{Sequence analysis}

A total of 204 differentially expressed fragments were selected from the resistance genotype Bukammen for further studies (Table 2). After reamplification and purification, the PCR products were sequenced directly without cloning. From the total number of fragments, 89 gave good quality sequences, which were used for searching in the NCBI and GDR databases. Of these 89 sequences, 36 (40\%) showed significant similarity to RGA sequences, while 53 (data not shown) were similar to other genes encoding, e.g., ATP synthase b subunits, ras proteins, ribosomal elongation factors, and adenylate kinase. Of the 36 fragments showing similarity to RGAs, 13, 15, and 8 were derived from the NBS-profiling involving primers NBS2, NBS3, and NBS5, respectively, while no RGAs resulted from the NBS7 primer (Table 2). Some of the 36 RGA fragments were multiplications, which resulted in 23 unique RGA fragments (Table 3). Some fragments were only expressed in the resistant genotype before infection (RGAs 2, 5, 109, and 169), while others were expressed in the early hours after infection (RGAs 124, 168, and 180) or as late as $196 \mathrm{~h}$ after infection (RGAs 156 and 159). In addition, a few fragments, like RGA116, were expressed at all harvesting points after infection (Table 3). Most (21) of these RGA fragment sequences gave significant hits $\left(E \leq 10^{-4}\right)$ to strawberry genes with the characteristic NBS-LRR motifs in NCBI and (or) GDR databases (Table 3).

Table 2 Summary of fragments derived from the $P$. cactorum resistant genotype Bukammen

\begin{tabular}{llrcc}
\hline Primer & $\begin{array}{l}\text { Polymorphic } \\
\text { fragments }\end{array}$ & RGA & $\begin{array}{l}\text { Other } \\
\text { genes }\end{array}$ & $\begin{array}{l}\text { Low quality } \\
\text { sequence }\end{array}$ \\
\hline NBS2 & 56 & 13 & 12 & 31 \\
NBS3 & 42 & 15 & 17 & 10 \\
NBS5 & 57 & 8 & 15 & 34 \\
NBS7 & 49 & 0 & 9 & 40 \\
Total & 204 & 36 & 53 & 115 \\
\hline
\end{tabular}




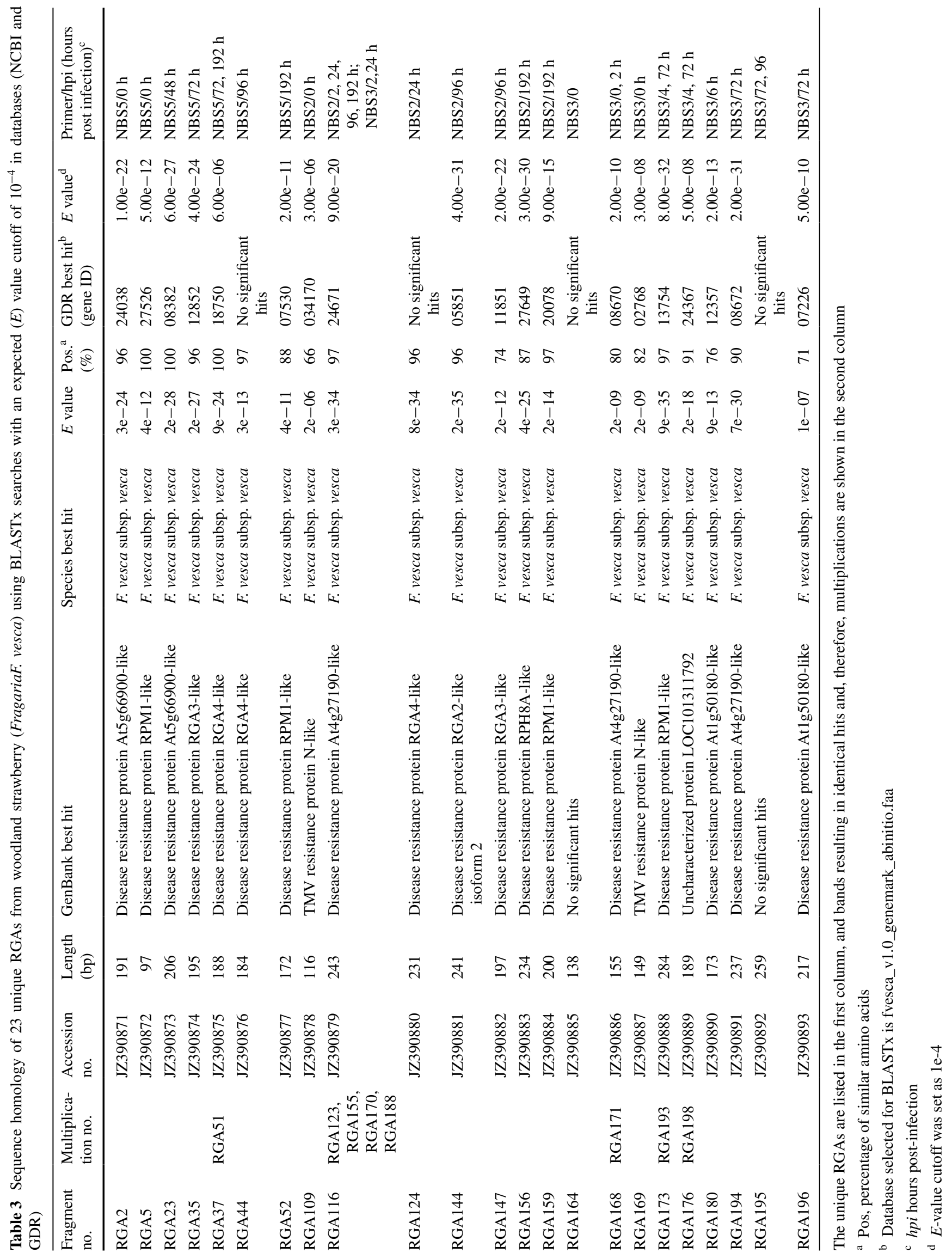




\section{Expression patterns of RGAs during the $\boldsymbol{P}$. cactorum infection}

All of 23 RGA fragment sequences were initially considered for real-time RT-PCR analyses to confirm the appropriateness of the applied technique as well as to monitor expression profiles of the corresponding genes during strawberry infection by $P$. cactorum. Six of the designed primer pairs failed to produce a single fragment, making them inappropriate for real-time RT-PCR. Therefore, 17 genes were studied in detail using real-time RT-PCR (Table 1).

Real-time RT-PCR analyses were performed using RNA isolated from the crown samples of the susceptible (FDP821) and resistance (Bukammen) genotypes interacting with the pathogen. The gene expression profiles show that the response of most of the RGAs (15 out of 17 genes) was quicker and stronger in the resistance genotype Bukammen than in the susceptible FDP821 during the very early infection stage (4 hpi) (Fig. 1). The expression of the other two genes (RGAs 159 and 196) was not significantly affected by the pathogen infection at 4 hpi. Surprisingly, the expression level of 11 RGAs (RGAs 37, 109, 116, 124, $144,159,173,176,194,195$, and 196) peaked at 192 hpi in Bukammen plants that were wounded but not inoculated. In FDP821, the expression of 8 RGAs (RGAs 2, 37, 52, 116, $147,156,194$, and 196) was relatively stable through the infection, whereas the other 9 RGAs peaked at either 48 or 96 hpi.

One RGA (RGA109) was selected to be the first priority of cloning and further studies, because this gene was highly induced at the early infection stage (Fig. 1). As shown in Fig. 1, in Bukammen, the expression of RGA 109 peaked (5.5-fold) at $4 \mathrm{hpi}$, then dropped sharply.

\section{Cloning of RGA109 and sequence analysis}

For full length cloning of the gene ORF corresponding to fragment No. 109, primers were designed based on the full-length ORF sequence of GDR 034170 (Table 3). PCR was performed using the cDNA sample derived from the infected Bukammen crowns at $4 \mathrm{hpi}$. After cloning and sequencing, a 1892-bp fragment was obtained, which is a bit longer than the database annotated GDR $034170 \mathrm{cDNA}$ sequence (1407 bp).

This gene cDNA fragment showed $96 \%$ identity with GDR 034170 cDNA sequence but with three extra segments of sequences (positions 229-499, 10581127, 1706-1850) and one cytosine nucleotide deletion between position 1045 and 1046 (Fig. 2a). If the start codon was at position 1 as predicted by the automatic annotation, however, at position 517 , there was a stop codon 'TAA.' This stop codon would lead to a non-functional protein of only 172 amino acids long. If it was the case, this indicated that in Bukammen, GDR 034170 was apparently a pseudogene. However, as shown in Fig. 1, this gene in Bukammen was highly expressed during the early infection stage. The results suggested that GDR 034170 could be mis-annotated by the automatic annotation process. This is strongly supported when another start codon at position 611 in the Bukammen cDNA sequence is detected that leads to one putative NBS-LRR protein of 427 amino acids long but without a stop codon (Fig. 2a). This means that we have not sequenced the whole gene, but only its $5^{\prime}$ end (position 611-1892). This putative protein sequence was used in the following analysis.

BLASTP searches show that the Bukammen 034170 protein is highly similar to a number of putative resistance proteins in F. vesca subsp. vesca and other plant species as well. The Bukammen 034170 protein gave the best similarity ( $89 \%$ identity; $E$ value $=0$ ) to one disease resistance protein, At4g27190-like of strawberry line 'Hawaii 4'. They shared two segments of amino acids (Fig. 2b). The best similarity in other plants was found to be a Vitis vinifera disease resistance At4g27190-like protein (54\% identity; $E$ value $=9 \mathrm{e}-144$ ) (Fig. 2c). Multiple sequence alignment showed that the Bukammen 034170 protein contains both NBS-ARC and LRR regions and the characteristic motifs, such as P-loop, RNBS-C, GLPL, MHD, and LRR, were shared between $F$. vesca, V. vinifera, Populus trichocarpa, and Solanum tuberosum (Fig. 2c). The results indicated that GDR 034170 in Bukammen is probably an NBS-LRR $R$ gene.

\section{Discussion}

So far, most components and mechanisms of the strawberry disease defense network remain marginally understood. Only a few published studies in strawberry have focused on gene discovery related to the mechanism of disease defense, and these have been related to defense against Colletotrichum acutatum (Casado-Díaz et al. 2006; Encinas-Villarejo et al. 2009; Guidarelli et al. 2011). In our study, we detect $R G A$ genes differentially expressed in the resistant strawberry genotype Bukammen relative to susceptible FDP821 after infection with P. cactorum. Although the handling of genomic DNA as template is easier and the average percentage of polymorphic fragments obtained using genomic DNA is higher than for cDNA (Brugmans et al. 2008), using cDNA as template can be instrumental in identifying $R$ genes that are transcribed, and thus putatively functional. A total of 204 cDNA-derived polymorphic fragments from Bukammen were collected, amplified, and sequenced for 

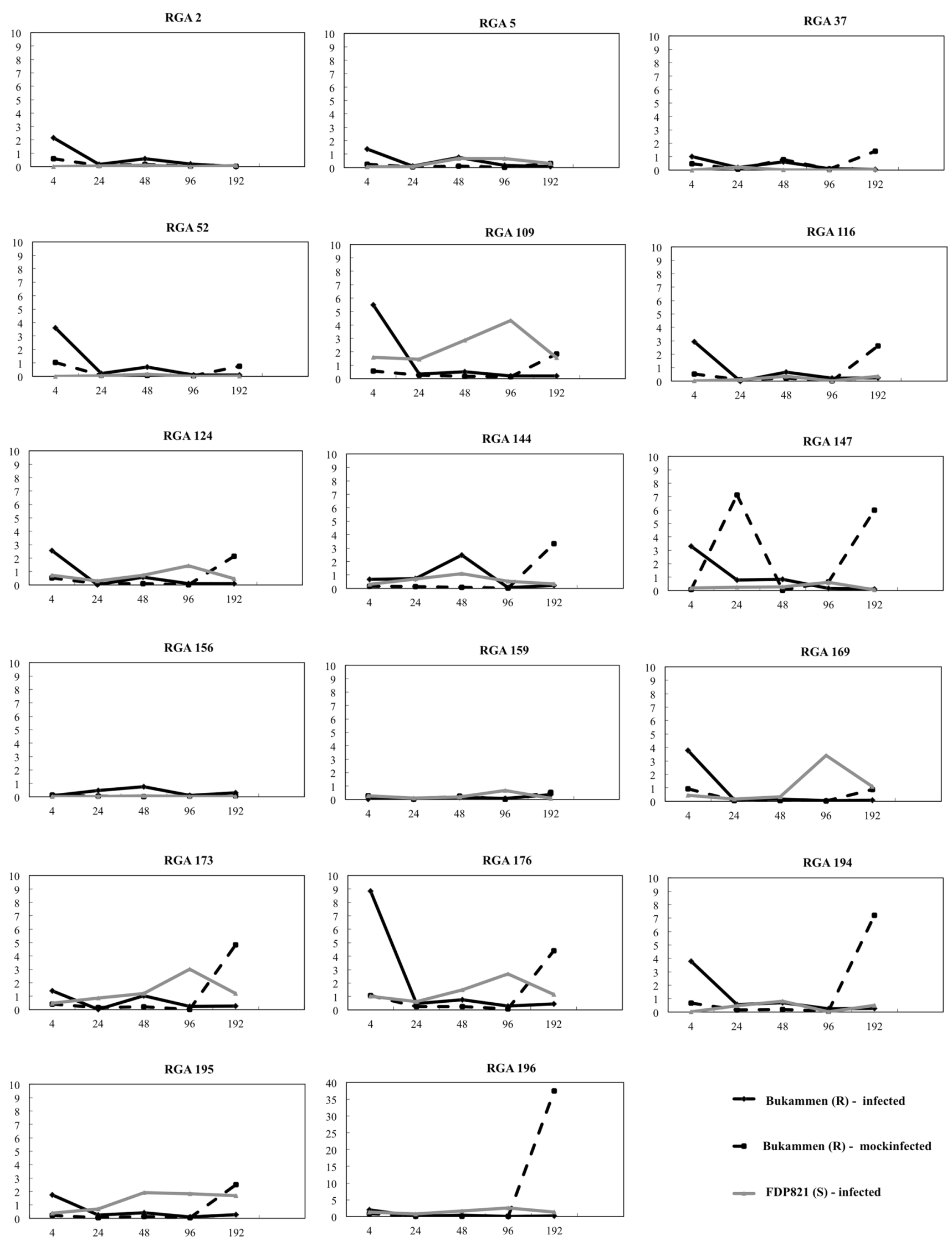
४Fig. 1 Expression profiles of 17 strawberry RGAs during a $P$. cactorum infection course [4, 24, 48, 96, and $192 \mathrm{~h}$ post-infection (hpi)]. Samples from the susceptible FDP821 genotype (inoculated) are labeled FDP821. Those not labeled 'FDP' came from the P. cactorum resistant Bukammen genotype in which 'Infected' means inoculated with $P$. cactorum, and 'Wounded' means only wounded by razor and mock-inoculated. Expression values for all genes are relative to those of Bukammen 0 hpi (calibrator)

characterization. Out of these, 89 cDNA derived fragments gave good quality sequences, of which 36 cDNA derived fragments were similar to $R$ gene or RGA sequences, resulting in 23 distinct strawberry RGAs (Table 3). Recently, 144 NBS-LRR genes were predicted from the sequenced diploid strawberry genome (Zhong et al. 2015). The reason why NBS profiling allowed us to detect a few $R G A$ genes from strawberry could be first due to the sequencing strategy that we used. Cloning of fragments before sequencing could have increased the number of good quality sequences and, therefore, also the number of RGA fragments. In addition, the NBS-specific primers were originally designed on the basis of an alignment of NBS-LRR class of known $R$ genes (van der Linden et al. 2004; Wang et al. 2008). Although such degenerate primers can recognize a large number of NBSLRR gene family members, it is conceivable that the primer selectivity is biased toward already known $R$ genes. With sequence data accumulating in a number of plant species, it should be possible to further optimize primer sequences to efficiently target more RGAs. Nevertheless, the results of this study showed that a relatively high number of the fragments $(17.6 \%)$ were truly derived from RGAs. This is in agreement with the previous findings of, e.g., both van der Linden et al. (2004) and Brugmans et al. (2008) who found that the majority of the fragments amplified by NBS profiling were RGA derived.

A few studies have shown that some $R$ genes are upregulated in response to pathogen invasion, suggesting that plants can establish a state of increased sensitivity to pathogen attack (Navarro et al. 2004; Zipfel et al. 2004; CasadoDíaz et al. 2006). Of the 23 RGAs obtained, in our study, 6 originated from the control samples (Bukammen crowns wounded only) at time $0 \mathrm{hpi}$, while the majority of differentially expressed fragments after infection were isolated from 72, 96, and 192 hpi (Table 3; Fig. 1). This result indicated that the resistant Bukammen contains some resistance genes that are constitutively expressed, while others are induced by infection which is in line with the situation described in potato (Ronnings et al. 2003), strawberry (Casado-Díaz et al. 2006) and banana (Emediato et al. 2013). The expression profile of seventeen of the RGAs identified by NBS profiling showed that the response of most RGAs $(15 / 17)$ was quicker and stronger in the resistance genotype Bukammen than in the susceptible one 'FDP821' during the early infection stage (Fig. 1). This is the same as described in Musa acuminate ssp. burmannicoides leaves inoculated with the fungal conidiospores of Mycosphaerella musicola (Emediato et al. 2013). They found that both in susceptible and resistant genotypes, some RGA genes were constitutively expressed across the infection time course, while some RGAs had low levels of expression at early infection stages and were upregulated in late stages. These results, together with our findings, highlight the importance of considering the transcriptional changes of RGAs during the pathogen infection to fully understand the mechanism of defense.

Resistance gene-mediated breeding is the most suitable strategy to control diseases and genetic transformation of Fragaria has made notable progress (Oosumi et al. 2006). Strawberry plants resistant to fungal diseases have been made using genes coding for chitinase from rice and Chile tomato, respectively, and a rice thaumatin II gene (thau II) (Asao et al. 1997; Chalavi et al. 2003; Schestibratov and Dolgov 2005). However, none of these genes belong to the NBS-LRR category of $R$ genes. The exact roles of NBS-LRR RGAs obtained in strawberry defense against $P$. cactorum infection are still to be determined. Based on our findings, we postulate that the $5^{\prime}$ end of one RGA (GDR034170) in Bukammen has been cloned, and the characteristic motifs shared with other plant species were detected (Fig. 2). Further studies will include isolation of full-length cDNAs of selected genes, gene knockout or RNA interference to test their functions in crown rot resistance. Candidate gene application via plant transformation or marker-assisted selection will benefit strawberry breeding programs for the generation of resistant genotypes.

The results presented here clearly demonstrate that NBS profiling is a powerful technique that relatively easy isolates strawberry RGAs with altered expression in response to infection. The molecular basis of the interaction between diploid strawberry (F. vesca) and P. cactorum from a plant defense perspective has been characterized, and the results provide a first insight into the strawberry NBS-LRR RGAs responding to $P$. cactorum infection at molecular level. A comprehensive analysis of RGAs in the future will lead to a better understanding of the mechanisms involved in strawberry plant defense and contribute to the design of molecular strategies to improve disease resistance of strawberry plants. 
(A) Genome project 34170 CDNA
Bukammen 34170 CDNA Genome project 34170 cDNA
Bukammen 34170 cDNA Genome project 34170 CDNA
Bukammen 34170 c CDNA

\section{Genome project $34170 \mathrm{CDNA}$
Bukammen $34170 \mathrm{CDNA}$}

Genome project 34170 CDNA Bukammen 34170 cDNA

Genome project $34170 \mathrm{CDNA}$ Bukammen 34170 cDNA

Genome project 34170 CDNA Bukammen 34170 cDNA

Genome project $34170 \mathrm{CDNA}$ Bukammen 34170 cDNA Genome project $34170 \mathrm{CDNA}$ (B) Fragaria vesca 034170
Fragaria vesco At4g27190-like Fragaria vesca 034170 Frogaria vesco At4927190-like Fragaria vesca 034170
Fragaria vesca At4927190.like Fragaria vesca At4g27190. Fragaria vesca 034170 Fragaria vesco At4927190-like Fragaria vesca 034170
Fragaria vesco At4g27190-like

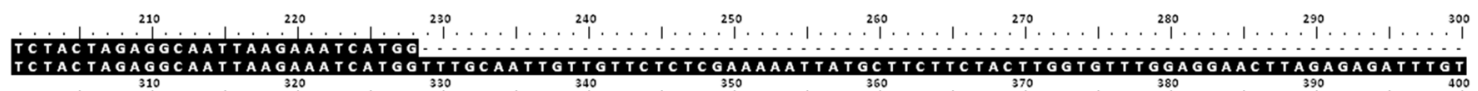

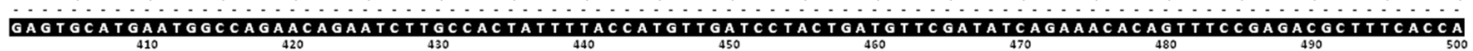

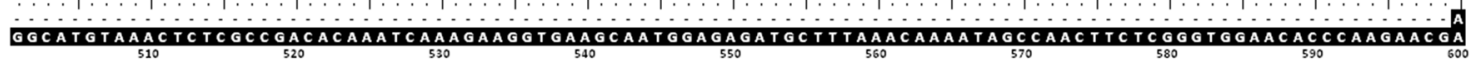

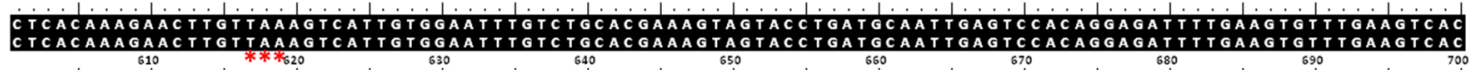
CAGACGTGCAATGTATGAGGTTATGAAGGCGTTTACAGATGATGAGGTCACTGCCATTGGTGTCTACAGCATGGGAGGCGTTGGAAAGACAACCCTGGTA
CAGACGTGCAATGTATGAGGTTATGAGGCGTTTACAGATGATGAGGTCACTGCCATTGGTGTCTACAGCATGGGAGGCGTTGGAAAGACAACCCTGGIA

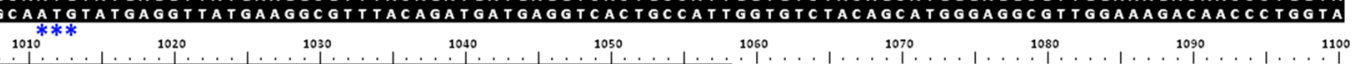

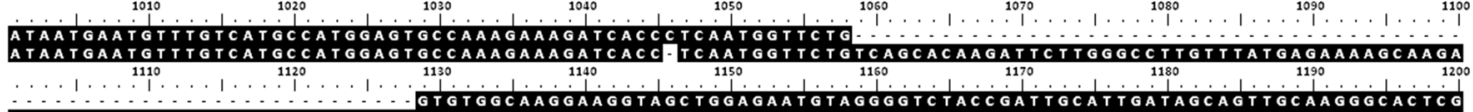

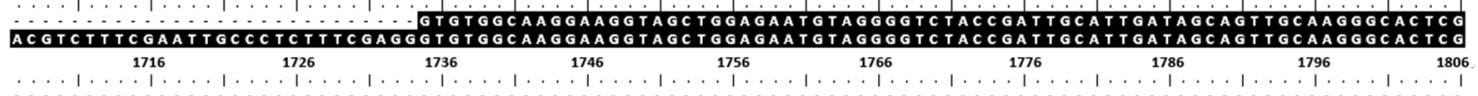
GTATGTCCAAAACTCCAGATTTTGTTICTAAACTTGTTTCTAAACCGTAATATTTATATAAAATATATACCTGAGACATTCTTCCAAGGTCCATATGAGT
1816 1826

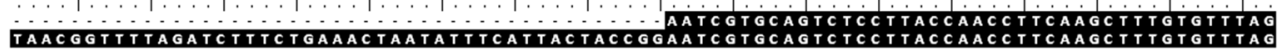

\section{(C)}

Fragaria vesc
Vitis vinifera Populus trichocarpo
Solanum tuberosum

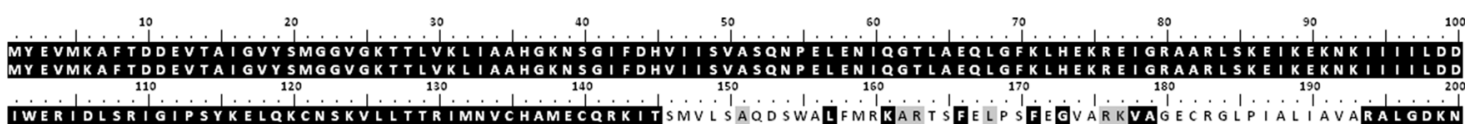

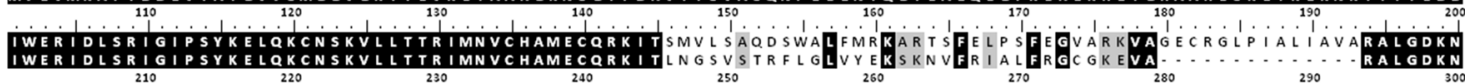

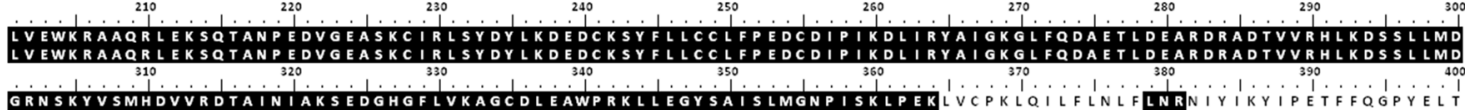

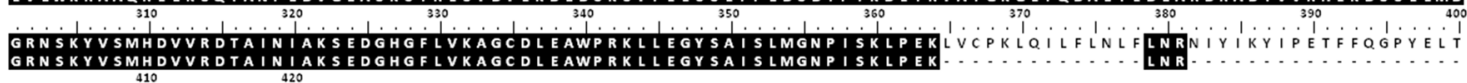
VIDLSETNISLIPESCSLITINLAALCi solanum tuberosum

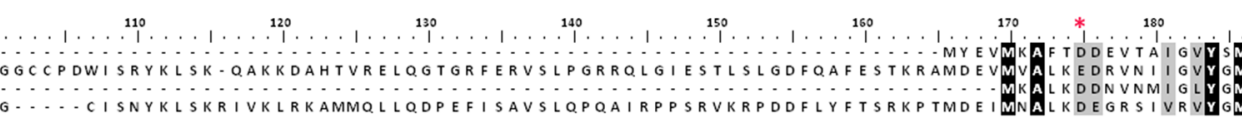

210
IF

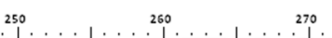<smiles>C1=[N+]2[Al][As]12</smiles>
P-loop

\section{Fragaria vesca 034170




\section{Compliance with ethical standards}

Conflict of interest All the authors declare no conflict of interests.

Ethical approval This article does not contain any studies with human participants or animals performed by any of the authors.

Open Access This article is distributed under the terms of the Creative Commons Attribution 4.0 International License (http://creativecommons.org/licenses/by/4.0/), which permits unrestricted use, distribution, and reproduction in any medium, provided you give appropriate credit to the original author(s) and the source, provide a link to the Creative Commons license, and indicate if changes were made.

\section{References}

Alsheikh M, Suso H-P, Robson M, Battey N, Wetten A (2002) Appropriate choice of antibiotic and Agrobacterium strain improves transformation of antibiotic-sensitive Fragaria vesca and $F$. v. semperflorens. Plant Cell Rep 20:1173-1180

Altschul SF, Madden TL, Schäffer AA, Zhang J, Zhang Z, Miller W, Lipman DJ (1997) Gapped BLAST and PSI-BLAST: a new generation of protein database search programs. Nucleic Acids Res 25(17):3389-3402

Asao H, Nishizawa Y, Arai S, Sato T, Hirai M et al (1997) Enhanced resistance against a fungal pathogen Spaerothecea humuli in transgenic strawberry expressing a rice chitinase gene. Plant Biotech 14:145-149

Brugmans B, Wouters D, van Os H, Hutten R, van der Linden G, Visser RG, van Eck HJ, van der Vossen EA (2008) Genetic mapping and transcription analyses of resistance gene loci in potato using NBS profiling. Theor Appl Genet 117(8):1379-1388

Calenge F, Van der Linden CG, Van de Weg E, Schouten HJ, Van Arkel G, Denance C, Durel CE (2005) Resistance gene analogues identified through the NBS profiling method map close to major genes and QTL for disease resistance in apple. Theor Appl Genet 110:660-668

Casado-Díaz A, Encinas-Villarejo S, Santos BDL, Schilirò E, YuberoSerrano E-M, Amil-Ruíz F, Pocovi MI, Pliego-Alfaro F, Dorado G, Rey M, Romero F, Muñoz-Blanco J, Caballero J-L (2006) Analysis of strawberry genes differentially expressed in response to Colletotrichum infection. Physiol Plantarum 128:633-650

Chalavi V, Tabaeizadeh Z, Thibodeau P (2003) Enhanced resistance to Vertkillium dahliae in transgenic strawberry plants expressing a Lycopersicon chilense chitinase gene. J Am Soc Hort Sci 128:747-753

Chen X, Klemsdal SS, Brurberg MB (2011) Identification and analysis of Phytophthora cactorum genes up-regulated during cyst germination and strawberry infection. Curr Genet 57(5):297-315

Cipriani G, Pinosa F, Bonoli M, Faedi W (2006) A new set of microsatellite markers for Fragaria species and their application in linkage analysis. J HorticSci Biotech 81:668-675

Dangl JL, Jones JD (2001) Plant pathogens and integrated defence responses to infection. Nature 411(6839):826-833

Davis TM, Yu H (1997) A linkage map of the diploid strawberry Fragaria vesca. J Hered 88:215-221

Davis T, Denoyes-Rothan B, Lerceteau-Kohler E (2007) Strawberry. In: Kole (ed) Genome mapping and molecular breeding in plants IV: Fruits and Nuts. Springer, Berlin, pp 189-206

Denoyes-Rothan B, Lerceteau-Köhler E, Guèrin G, Bosseur S, Bariac J, Martin E, Roudeillac P (2004) QTL analysis for resistances to Colletotrichum acutatum and Phytophthora cactorum in octoploid strawberry (FragariaXananassa). Acta Hort 663:147-151
Eikemo H, Brurberg MB, Davik J (2010) Resistance to Phytophthora cactorum in diploid Fragaria species. Hortic Sci 45:193-197

Emediato FL, Passos MAN, de Camargo Teixeira C, Pappas GJ Jr, Miller RNG (2013) Analysis of expression of NBS-LRR resistance gene analogs in Musa acuminate during compatible and incompatible interactions with Mycosphaerella musicola. Acta Hortic 986:255-258

Encinas-Villarejo S, Maldonado AM, Amil-Ruiz F, de los Santos B, Romero F, Pliego-Alfaro F, Muñoz-Blanco J, Caballero JL. (2009) Evidence for a positive regulatory role of strawberry (Fragaria $\times$ ananassa) Fa WRKY1 and Arabidopsis At WRKY75 proteins in resistance. J Exp Bot 60:3043-3065

Erwin DC, Ribeiro OK (1996) Phytophthora diseases worldwide [M]. APS Press, St Paul

Flor HH (1942) Inheritance of pathogenicity in Melampsora lini. Phytopathology 32:653-669

Flor H (1971) Current status of the gene-for-gene concept. Annu Rev Phytopathol 9:275-296

Folta KM, Davis TM (2006) Strawberry genes and genomics. Crit Rev Plant Sci 25:399-415

Guidarelli M, Carbone F, Mourgues F, Perrotta G, Rosati C, Bertolini P, Baraldi E (2011) Colletotrichum acutatum interactions with unripe and ripe strawberry fruits and differential responses at histological and transcriptional levels. Plant Pathol 60(4):685-697

Gururani MA, Venkatesh J, Upadhyaya CP, Nookaraju A, Pandey SK, Park SW (2012) Plant disease resistance genes: Current status and future directions. Physiol Mol Plant P 78:51-65

Hall TA (1999) BioEdit: a user-friendly biological sequence alignment editor and analysis program for Windows 95/98/NT. Nucl Acid S 41:95-98

Jacobs MM, Vosman B, Vleeshouwers VG, Visser RG, Henken B, van den Berg RG (2010) A novel approach to locate Phytophthora infestans resistance genes on the potato genetic map. Theor Appl Genet 120(4):785-796

Jo KR, Arens M, Kim TY, Jongsma MA, Visser RG, Jacobsen E, Vossen JH (2011) Mapping of the S. demissum late blight resistance gene $R 8$ to a new locus on chromosome IX. Theor Appl Genet 123(8):1331-1340

Jung S, Cho I, Sosinski B, Abbott A, Main D (2010) Comparative genomic sequence analysis of strawberry and other rosids reveals significant microsynteny. BMC Res Notes 3:168

Lerceteau-Köhler E, Guérin G, Laigret F, Denoyes-Rothan B (2003) Characterization of mixed disomic and polysomic inheritance in the octoploid strawberry (Fragaria $\times$ ananassa) using AFLP mapping. Theor App Genet 107:619-628

Liang Z, Drijber RA, Lee DJ, Dwiekat IM, Harris SD, Wedin DA (2008) A DGGE-cloning method to characterize arbuscular mycorrhizal community structure in soil. Soil Biol Biochem 40(4):956-966

Maas JL (1998) Compendium of strawberry diseases. Compendium of strawberry diseases APS press, St. Paul

Malosetti M, van der Linden CG, Vosman B, van Eeuwijk FA (2007) A mixed-model approach to association mapping using pedigree information with an illustration of resistance to Phytophthora infestans in potato. Genetics 175(2):879-889

Mantovani P, van der Linden G, Maccaferri M, Sanguineti MC, Tuberosa R (2006) Nucleotide-binding site (NBS) profiling of genetic diversity in durum wheat. Genome 49(11):1473-1480

Martínez-Zamora MG, Castagnaro AP, Diaz-Ricci JC (2004) Isolation and diversity analysis of resistance gene analogues (RGAs) from cultivated and wild strawberries. Mol Genet Genomics 272:480-487

Meyers BC, Morgante M, Michelmore RW (2002) TIR-X and TIRNBS proteins: two new families related to disease resistance TIR-NBS-LRR proteins encoded in Arabidopsis and other plant genomes. Plant J 32:77-92 
Meyers BC, Kozik A, Griego A, Kuang H, Michelmore RW (2003) Genome-wide analysis of NBS-LRR encoding genes in Arabidopsis. Plant Cell 15:809-834

Monosi B, Wisser RJ, Pennill L, Hulbert SH (2004) Full genome analysis of resistance gene homologues in rice. Theor Appl Genet 109:1434-1447

Navarro L, Zipfel C, Rowland O, Keller I, Robatzek S, Boller T, Jones JD (2004) The transcriptional innate immune response to flg22. Interplay and overlap with Avr gene-dependent defense response and bacterial pathogenesis. Plant Physiol 135:1113-1128

Oosumi T, Gruszewski H, Blischak L, Baxter A, Wadl P, Shuman J, Veilleux RE, Shulaev V (2006) High-efficiency transformation of the diploid strawberry (Fragaria vesca) for functional genomics. Planta 223:1219-1230

Pattison JA, Samuelian SK, Weber CA (2007) Inheritance of Phytophthora root rot resistance in red raspberry determined by generetion means and molecular linkage analysis. Theor Appl Genet 115:225-236

Perazzolli M, Malacarne G, Baldo A, Righetti L, Bailey A, Fontana P, Velasco R, Malnoy M (2014) Characterization of resistance gene analogues $(R G A s)$ in apple (Malus $\times$ domestica Borkh.) and their evolutionary history of the Rosaceae family. PLoS One 9(2):e83844

Pfaffl MW (2001) A new mathematical model for relative quantification in real-time RT-PCR. Nucleic Acids Res 29:e45

Pfaffl MW, Horgan GW, Dempfle L (2002) Relative expression software tool (RESTC) for group-wise comparison and statistical analysis of relative expression results in real-time PCR. Nuc Acids Res 30(9):e36

Pfaffl MW, Tichopad A, Prgomet C, Neuvians TP (2004) Determination of stable housekeeping genes, differentially regulated target genes and sample integrity: BestKeeper-Excel-based tool using pair-wise correlations. Biotechnol Lett 26:509-515

Ronnings CM, Stegalkina SS, Ascenzi RA, Bougri O, Hart AL, Utterbach TR, Vanaken SE, Riedmuller SB, White JA, Cho J, Pertea GM, Lee Y, Karamycheva S, Sultana R, Tsai J, Quackenbush J, Griffiths HM, Restrepo S, Smart CD, Fry WE, Van Der Hoeven R, Tanksley S, Zhang P, Jin H, Yamamoto ML, Baker BJ, Buell C (2003) Comparative analyses of potato expressed sequence tag libraries. Plant Physiol 131:419-429

Rousseau-Gueutin M, Lerceteau-Köhler E, Barrot L, Sargent DJ, Monfort A, Simpson D, Arus P, Guerin G, Denoyes-Rothan B (2008) Comparative genetic mapping between octoploid and diploid Fragaria species reveals a high level of colinearity between their genomes and the essential disomic behavior of the cultivated octoploid strawberry. Genetics 179:2045-2060

Rousseau-Gueutin M, Gaston A, Ainouche A, Ainouche ML, Olbricht K, Staudt G, Richard L, Denoyes-Rothan B (2009) Tracking the evolutionary history of polyploidy in Fragaria L (strawberry): new insights from phylogenetic analyses of low-copy nuclear genes. Mol Phylogenet Evol 51:515-530

Sambrook J, Fritsch EF, Maniatis T (1989) Molecular cloning: a laboratory manual, 2nd edn. Cold Spring Harbor Laboratory Press, Cold Spring Harbor, pp 10.59-10.67, 11.31-11.33

Sargent DJ, Davis TM, Tobutt KR, Wilkinson MJ, Battey NH, Simpson DW (2004) A genetic linkage map of microsatellite, genespecific and morphological markers in diploid Fragaria. Theor App Genet 109:1385-1391
Sargent DJ, Clarke J, Simpson DW, Tobutt KR, Arús P, Monfort A, Vilanova S, Denoyes-Rothan B, Rousseau M, Folta K, Bassil NV, Battey NH (2006) An enhanced microsatellite map of diploid Fragaria. Theor App Genet 112:1349-1359

Schestibratov KA, Dolgov SV (2005) Transgenic strawberry plants expressing a thaumatin II gene demonstrate enhanced resistance to Botrytis cinerea. Sci Hortic 106:177-189

Sharma TR, Das A, Kumar SP, Lodha ML (2009) Resistance gene analogues as a tool for rapid identification and cloning of disease resistance genes in plants-a review. J Plant Biochem Biot 18(1): $1-11$

Shaw DV, Hansen J, Browne GT (2006) Genotypic variation for resistance to Phytophthora cactorum in a California strawberry breeding population. J Amer Soc Hort Sci 131:687-690

Shaw DV, Hansen J, Browne GT, Shaw SM (2008) Components of genetic variation for resistance of strawberry to Phytophthora cactorum estimated using segregating seedling populations and their parent genotypes. Plant Pathol 57:210-215

Shulaev V, Sargent DJ, Crowhurst RN, Mockler TC, Folkerts O, Delcher AL, Jaiswal P, Mockaitis K, Liston A, Mane SP, Burns P, Davis TM, Slovin JP, Bassil N, Hellens RP, Evans C, Harkins T, Kodira C, Desany B, Crasta OR, Jensen RV, Allan AC, Michael TP, Setubal JC, Celton JM, Rees DJ, Williams KP, Holt SH, Ruiz Rojas JJ, Chatterjee M, Liu B, Silva H, Meisel L, Adato A, Filichkin SA, Troggio M, Viola R, Ashman TL, Wang H, Dharmawardhana P, Elser J, Raja R, Priest HD, Bryant DW Jr, Fox SE, Givan SA, Wilhelm LJ, Naithani S, Christoffels A, Salama DY, Carter J, Lopez Girona E, Zdepski A, Wang W, Kerstetter RA, Schwab W, Korban SS, Davik J, Monfort A, Denoyes-Rothan B, Arus P, Mittler R, Flinn B, Aharoni A, Bennetzen JL, Salzberg SL, Dickerman AW, Velasco R, Borodovsky M, Veilleux RE, Folta KM (2011) The genome of woodland strawberry (Fragaria vesca). Nat Genet 43:109-116

Syed NH, Sørensen AP, Antonise R, van de Wiel C, van der Linden CG, van ' $t$ Westende W, Hooftman DA, den Nijs HC, Flavell AJ (2006) A detailed linkage map of lettuce based on SSAP, AFLP and NBS markers. Theor Appl Genet 112:517-527

van de Weg WE (1997) Resistance to Phytophthora fragariae var. fragariae in strawberry: the Rpf2 gene. Theor Appl Genet 94(8):1092-1096

van der Linden CG, Wouters DCAE, Mihalka V, Kochieva EZ, Smulders MJM, Vosman B (2004) Efficient targeting of plant disease resistance loci using NBS profiling. Theor Appl Genet 109:384-393

Wang M, Berg RG, Linden GC, Vosman B (2008) The utility of NBS profiling for plant systematics: a first study in tuber-bearing Solanum species. Plant Syst Evol 276:137-148

Weebadde CK, Wang D, Finn CE, Lewers KS, Luby JJ, Bushakra J, Sjulin TM, Hancock X (2008) Using a linkage mapping approach to identify QTL for day-neutrality in the octoploid strawberry. Plant Breeding 127:94-101

Zhong Y, Yin H, Sargent DJ, Malnoy M, Cheng ZM (2015) Speciesspecific duplications driving the recent expansion of NBS-LRR genes in five Rosaceae species. BMC Genom 16:77

Zipfel C, Robatzek S, Navarro L, Oakeley EJ, Jones JD, Felix G, Boller T (2004) Bacterial disease resistance in Arabidopsis through flagellin perception. Nature 428:764-767 